\title{
QUALITY OF LIFE OF RELATIVE CAREGIVERS OF ELDERLY DEPENDENTS AT HOME
}

\author{
Karla Ferraz dos Anjos ${ }^{1}$, Rita Narriman Silva de Oliveira Boery², Rafael Pereira ${ }^{3}$
}

\footnotetext{
${ }^{1}$ Nurse. Master in Nursing and Health. Jequié, Bahia, Brazil. E-mail: karla.ferraz@hotmail.com

2 Ph.D. in Nursing. Full Professor of the Graduate Program in Nursing and Health of Universidade Estadual do Sudoeste da Bahia (UESB). Jequié, Bahia, Brazil. E-mail: rboery@gmail.com

${ }^{3}$ Ph.D. in Biomedical Engineering. Assistant Professor at UESB. Jequié, Bahia, Brazil. E-mail: rafaelppaula@gmail.com
}

\begin{abstract}
The objective of this study was to analyze the relationship of sociodemographic characteristics and activity overload with the quality of life of relative caregivers of elderly dependents at home. This is an epidemiological, transversal study, conducted with 58 relative caregivers of elderly people registered in Family Health Programs in a municipality in the state of Bahia. Sociodemographic data were collected; in addition, the Katz Index of Independence, Zarit Burden Interview, and WHOQOL-bref were administered. The data were analyzed using correlation and multiple linear regression. The Zarit scale was negatively associated with all areas of the WHOQOL-bref domain, which was corroborated by the multiple regression model, which identified that the Zarit scale alone was able to predict the impact of care on quality of life of the studied caregivers. There is evidence of a need for expansion of social and health support to caregivers in an attempt to minimize overload, improving the quality of life of these individuals.
\end{abstract}

DESCRIPTORS: Caregivers. Family. Aged. Quality of life. Social support.

\section{QUALIDADE DE VIDA DE CUIDADORES FAMILIARES DE IDOSOS DEPENDENTES NO DOMICÍLIO}

RESUMO: Objetivou-se analisar a associação de características sociodemográficas e sobrecarga de atividades com a qualidade de vida do cuidador familiar de idosos dependentes no domicílio. Estudo epidemiológico, transversal, realizado com 58 cuidadores familiares de idosos, cadastrados em Estratégias Saúde da Família de um município do interior do Estado da Bahia. Os dados foram coletados a partir dos instrumentos de Katz, sociodemográfico, Zarit Burden Interview, WHOQOL-bref e analisados pela estatística descritiva, de correlação e regressão linear múltipla. A escala Zarit associou-se negativamente com todos os domínios do WHOQOL-bref. Corroborando este achado, o modelo de regressão múltipla aplicado identificou que a escala Zarit isoladamente é capaz de predizer os impactos do cuidar sobre a qualidade de vida dos cuidadores estudados. Há evidência da necessidade de ampliação do suporte social e de saúde aos cuidadores na tentativa de minimizar a sobrecarga, melhorando a qualidade de vida desses indivíduos.

DESCRITORES: Cuidadores. Família. Idoso. Qualidade de vida. Apoio social.

\section{CALIDAD DE VIDA DE FAMILIARES CUIDADORES DE ANCIANOS DEPENDIENTES EN CASA}

RESUMEN: Se objetivó analizar la asociación de las características socio-demográficas y sobrecarga de actividades con la calidad de vida de familiares cuidadores de ancianos dependientes en casa. Estudio epidemiológico, transversal, realizado con 58 cuidadores familiares de personas mayores, registrado en Estrategias de Salud de la Familia, de un municipio del estado de Bahía. Los datos fueron recolectados por medio de instrumentos sociodemográficos, además del Katz Index of Independence, Zarit Burden Interview, y el WHOQOL-bref, que fueron analizados mediante estadística descriptiva, de correlación y regresión lineal múltiple. La escala Zarit se asoció negativamente con todas las áreas del WHOQOL-bref. Corroborando este hallazgo, el modelo de regresión múltiple aplicado identificó que la escala Zarit sola es capaz de predecir el impacto del cuidado sobre la calidad de vida de los cuidadores estudiados. Hay evidencia de la necesidad de expansión de la ayuda social y de la salud a los cuidadores, en un intento de minimizar la sobrecarga, mejorando la calidad de vida de estos individuos.

DESCRIPTORES: Cuidadores. Familia. Anciano. Calidad de vida. Apoyo social. 


\section{INTRODUCTION}

The increase in the number of elderly people in the general population is a result of positive gains in social development. However, with an increase in life expectancy and issues associated with the human aging process, there is an increase in risk factors that are primarily related to chronic noncommunicable diseases, raising concern toward comorbidity statistics. This may compromise the independence of the elderly population and cause these individuals to constantly require assistance from caregivers who must perform daily, basic care. ${ }^{1}$

To provide care is to offer others, in the form of service, the results of your talents, preparation and choices. It is to practice care, perceiving the other person as they are and as they show themselves, their gestures and speech, their pain and limitations. Providing care involves attention, precaution, dedication, affection, duty and responsibility. The caregiver is the person chosen, usually by the family, to perform care when necessary. ${ }^{2}$

The relative caregiver is usually the individual who is responsible for caring for a person in his or her own family, also known as an informal caregiver. The informal caregiver may be a family member, such as a spouse, son or daughter, or sibling, or a friend or neighbor who cares for someone, even though they have no kinship ties. The main caregiver is the individual who is responsible for most daily work with the dependent elderly. ${ }^{3}$

In this context, it is notable that in most cases the family is tasked with the voluntary care of the elderly dependent in the home. They are thus part of an informal social support network, and function as partners of the formal social support networks formed by health professionals with special qualifications, especially as represented by health services. ${ }^{4}$ Relative caregivers are responsible for caring for those who need it, although this care may significantly impact the quality of life (QL) of these caregivers.

Brazilian laws for the protection of the elderly population are based on the Federal Constitution, which contains the National Policy for the Elderly and the National Policy for the Health of Elderly Persons. In these laws, it is reiterated that it is the duty of the family and the obligation of the community, society and state to support elderly persons, ensure their participation in the community, defend their dignity and well-being, and guarantee their right to life. ${ }^{5-6}$
A study ${ }^{7}$ conducted in Portugal showed that the experience of home care in families has been greatly increasing in recent years. Conforming to that trend, policymakers for care of the elderly claim that home care may be best for the elderly. This is because of the probability of guaranteeing their autonomy and preserving their dignity and identity. The situation is similar in Brazil, where family members most frequently take responsibility for the care of the elderly.

The family context is the most effective environment for the elderly, providing support and belonging, as well as indispensable, pertinent and effective health care. Thus, the primary search for the figure of the caregiver is carried out within the family. ${ }^{8}$ In Brazil, it is estimated that $85 \%$ of elderly persons present at least one chronic disease. Furthermore, of these, around 10\% have overlapping concomitant afflictions. Therefore, the contemporary Brazilian situation of chronicity and longevity contributes to an increase in the elderly population with functional limitations, who demand constant daily care. ${ }^{9}$

Many people find themselves in a state of dependency, which generates frailty, and which, for reasons related to the lack or loss of physical and/or mental autonomy, requires care and/or help from other people to perform basic activities of daily living (BADL). This situation of frailty is a problem that carries many psychosocial, economic, political and financial implications, both for dependent individuals and for those who have to spend time caring for them. ${ }^{10}$

In Brazil, particularly, due to the socioeconomic factors, especially in areas with a low human development index (HDI), the role of the caregiver, considered a fundamental agent in the process of care and rehabilitation, is generated in the household itself.1-12 This situation sometimes brings change to the family $y^{11}$ and can sometimes be stressful, with health risk factors for caregivers, especially due to the possibility of an overload of daily care activities. This problem ${ }^{12}$ justifies the need for more investment in the education of these persons so that they can perform care more adequately, with less risk and within their capabilities.

Assuming responsibility of caring for elderly dependents has been described by relative caregivers as an exhausting and stressful task, since the caregivers experience restrictions and/or limitations on their own lives ${ }^{13}$, which can impact their 
QL. Even though care ${ }^{14}$ is considered an activity that requires responsibility and dedication, it must also be performed with love. It is influenced by recognition, obligation and duty, as well as feelings of affection, that are related to the moments lived with the elderly person.

In this context, one study ${ }^{15}$ verified the relationship between the subjective perception of QL of the relative caregivers of elderly dependents and the following characteristics: sociodemographics, health, degree of perceived overload and degree of the elderly person's functional independence. It was confirmed that the degree of overload is negatively correlated with the perception of QL; and that in conjunction, the degree of overload, the presence of a partner and the presence of disease in the caregiver are factors that better explain the perception of QL, as measured by the Quality of Life Index (QLI).

It is important to note that this study ${ }^{15}$ included elderly citizens who received care from the Family Health Program in the southern neighborhoods of the São Paulo state capital, which makes it impossible to extend the conclusions to caregivers who live in other parts of the country, especially areas with low HDI, since the state of São Paulo ${ }^{16}$ has a high HDI. This information is confirmed in the definition of QL, which, according to the World Health Organization, ${ }^{17}$ is individuals' own perceptions about their position in life, in regard to the culture and system of values in which they live and in regard to their objectives, expectations, standards and preoccupations.

Thus, it is necessary to carry out studies to verify the relationship between the subjective perception of QL of relative caregivers of elderly dependents and sociodemographics, health, degree of perceived overload and degree of the elderly person's functional independence in areas with low HDI. Such studies will allow acquisition of knowledge of the nature of this relationship in different social contexts, especially in Brazil, where there are no specific policies focused on caregivers. Thus, it is relevant to identify the factors associated with the care process and their influence on caregiver QL.

This objective of this study was to analyze the association of sociodemographic characteristics and activity overload with quality of life of relative caregivers of elderly dependents in the household, in a municipality in the interior of the state of Bahia.

\section{METHOD}

This is an epidemiological, transversal study, conducted in residences in an urban area linked to two Family Health Strategies in a municipality in the interior of the state of Bahia. The location is the northeastern area of Brazil, with a territorial area of 2,254.420 $\mathrm{km}^{2}$. The population is composed of 14,387 individuals, with 7,359 in the urban area and, of these, 871 being elderly citizens. Regarding social inequality and population poverty, this municipality is primarily composed, of individuals with low purchasing power. ${ }^{18}$

The Family Health Strategies have registered two teams, 14 microareas and 839 elderly citizens of 60 years of age or more. From this study, home visits were carried out with community health agents to identify elderly citizens with functional dependency, in accordance with Katz's Index of Activities of Daily Living (BADL) ${ }^{19}$ Data were gathered in January and February 2013, through semistructured interviews. The main author and a nurse qualified to performing field activities conducted the application of data gathering instruments.

The participants of the study were 58 relative caregivers of elderly people. Inclusion criteria were: relative caregivers of elderly people who present functional dependency and who are registered in one of the Family Health Strategies; cohabitation; aged 18 or over; and being the main caregiver.

To classify the elderly people as independent or dependent, the caregivers were interviewed using the Katz scale, an instrument developed to evaluate functional independence in performing the activities of daily living in six functions: bathing, dressing, going to the restroom, functional mobility, sphincter control and feeding. ${ }^{19}$ The score ranges from zero to six points, with one point given for each "Yes" answer, defining the individual as independent in all functions or dependent in one, two, three, four, five or six functions. ${ }^{19}$

After identifying the elderly dependents, their caregivers were studied. Initially, a semistructured form was administered to verify the sociodemographic and health characteristics of the caregivers. Afterward, to verify the caregivers' overload in relation to the care offered to the elderly person, the Zarit Burden Interview (ZBI) was carried out. This is an instrument composed of 22 items to evaluate areas linked to health, social and personal life, psychological well-being, finance and personal relationships. ${ }^{20}$ 
Each item in the ZBI scale is of the Likert type with five points, scored from 0 to 4 , which measure frequency and intensity ( $0=$ never; $4=$ always). In the last item, the participant is questioned about overload when performing the caregiver function ( $0=$ nothing; $4=$ extremely). The scale score ranges between 0 and 88 , with higher scores meaning higher overload. ${ }^{20}$

Caregiver QL was evaluated by administering the World Health Organization Quality of Life (WHOQOL-Bref) questionnaire. The instrument has 26 questions, two about general QL and 24 composed of four domains: physical, psychological, social relations and environment. The two generate a unique score independent of the others related to domains, which is called QLI. ${ }^{21}$

The data were processed using the Statistical using average and standard deviation (SD). Additionally, a Spearman correlation was performed between the WHOQOL-Bref domains and quantitative variables of the caregiver and elderly person, as well as the multiple linear stepwise forward regression model, having the QLI score as a dependent variable and, as independent variables, the ages of the caregiver and of the elderly person, the caregiver's gender, morbidity presence, and Katz and Zarit scales. For this study, only the QLI score was chosen, since it is considered a more comprehensive indicator, more adequate for the objectives of the study, as proposed in another study. ${ }^{15}$ The significance level adopted for the study was $5 \%$ (e.g., p<0.05).

To verify the correlation between WHOQOLbref domains and variables of the caregiver and of the elderly person, the Spearman Correlation Coefficient was used, with ranking according to the magnitude ${ }^{22} ;<0.3$ (weak), $\geq 0.3$ to $<0.5$ (moderate) and $\geq 0.5$ (strong).

The study was approved by the Research Ethics Committee of Southwest Bahia State University, Jequié campus, Bahia, under protocol $n$. 128.580/2012 and CAAE: 08643612.6.0000.0055.

\section{RESULTS}

Of the elderly people who received care; $65.5 \%$ were female, with an average age of 79.68 years $(\mathrm{SD}=11.5)$. The most commonly described diseases were hypertension (48.3\%) and cerebrovascular accident $(15.5 \%)$. With the Katz scale, it general questions were calculated in conjunction to Package for Social Science (SPP) software, version 18.0. Descriptive statistical analysis was chosen,

was identified that $44.9 \%$ of the elderly people were dependent in between three and five functions and $19 \%$ declared themselves as totally dependent, with a scale average of $4.55(\mathrm{SD}=1.89)$.

Table 2 shows the sociodemographic profile of the caregivers. The highest proportion was female $(84.5 \%)$, followed by a son or daughter $(77.6 \%)$. Other characteristics included race/biracial $(65.5 \%)$, in a stable relationship $(60.3 \%)$, average age 47.41 years (SD \pm 16.8$)$. Most indicated that they had an incomplete primary school education $(44.9 \%)$, were unemployed $(82.8 \%)$, had an income below minimum wage $(67.4 \%)$, spent more than 18 hours a day with care $(82.8 \%)$, had been caregiver for more than six years $(53.4 \%)$, referred to having some disease $(87.9 \%)$, and received help from other people in caring for the elderly person $(60.3 \%)$, as shown on table 1 .

Table 1 - Characteristics of relative caregivers in the study Quality of Life of Relative Caregivers of Elderly Dependents at Home. Manoel Vitorino, Bahia, 2013

\begin{tabular}{|c|c|}
\hline Variable & $\begin{array}{l}\text { Caregiv- } \\
\text { ers }(n=58)\end{array}$ \\
\hline \multicolumn{2}{|l|}{ Gender (\%) } \\
\hline Female & 84.5 \\
\hline Male & 15.5 \\
\hline \multicolumn{2}{|l|}{ Age (\%) } \\
\hline Average & 47.41 \\
\hline Standard deviation & 16.8 \\
\hline Minimum & 18 \\
\hline Maximum & 80 \\
\hline \multicolumn{2}{|l|}{ Skin Color $(\%)$} \\
\hline White & 25.9 \\
\hline Bi-Racial & 65.5 \\
\hline Black & 8.6 \\
\hline \multicolumn{2}{|l|}{ Marital status (\%) } \\
\hline Married/consensual relationship & 60.3 \\
\hline Single & 34.5 \\
\hline Widow/Widower & 5.2 \\
\hline \multicolumn{2}{|l|}{ Education $(\%)$} \\
\hline Illiterate & 22.4 \\
\hline Incomplete Primary School & 44.9 \\
\hline Complete Primary School & 8.6 \\
\hline Incomplete/complete High School & 17.3 \\
\hline Incomplete/complete College or over & 6.8 \\
\hline \multicolumn{2}{|l|}{ Number of hours/day dedicated to care (\%) } \\
\hline Up to 8 & 5.1 \\
\hline From 9 to 18 & 12.0 \\
\hline More than 18 hours/day or integral & 82.9 \\
\hline \multicolumn{2}{|l|}{ For how long have been caring (in years) (\%) } \\
\hline Up to 1 year & 10.4 \\
\hline
\end{tabular}




\begin{tabular}{lc} 
From 2 to 5 years & 36.2 \\
From 6 to 10 years & 32.6 \\
Over 10 years & 20.8 \\
Monthly income (minimum wages) $(\%)$ & \\
No income & 36.2 \\
Under 1 & 31.2 \\
Equal to 1 & 24.0 \\
Over 1 & 8.6 \\
Kinship with the elderly person (\%) & \\
Son/Daughter & 77.6 \\
Spouse & 15.5 \\
Father/Mother & 6.9 \\
Work (\%) & \\
Has paid work & 17.2 \\
Housewife/unemployed & 55.2 \\
Never had paid work & 27.6 \\
Presence of disease (\%) & \\
Yes & 87.9 \\
No & 12.1 \\
Receives help (\%) & \\
Yes & 60.3 \\
No & 39.7 \\
\hline
\end{tabular}

$\left(^{*}\right)$ Minimum wage $=\mathrm{R} \$ 620.00$.
In relation to the diseases referred to by the caregivers, there was a predominance of low back pain $(63.8 \%)$, followed by hypertension $(41.4 \%)$ and varicose veins $(37.9 \%)$, with $51.7 \%$ of the caregivers using some medication.

In the WHOQOL-bref, the QLI had an average of $55.6(\mathrm{SD}=9.8)$. The domains that showed the highest scores were physical (average of 54.8; median of $53.5 ; \mathrm{SD}=15.5$ ), social relationships (average of 54.8; median of 50; $\mathrm{SD}=15.5$ ); environment (average of 41.4; median of 42; $\mathrm{SD}=13.9$ ) presented the lowest scores.

Data from table 2 show the correlations between the WHOQOL-bref domains and variables of the caregiver and elderly person. The Zarit scale had a significant negative correlation of strong magnitude with the QLI and the physical, psychological and environment domains, in addition to a weak, although significant, correlation with the social relationships domain. Physical domain had weak correlation with the caregiver's age, as well as the psychological and social relationships domains in the Katz scale.

Table 2 - Spearman correlation coefficients $\left(r_{s p}\right)$ between the WHOQOL-bref domains and the remaining variables in the study Quality of Life of the Relative Caregiver of Elderly Dependents at Home. Manoel Vitorino ,Bahia, 2013

\begin{tabular}{|c|c|c|c|c|c|c|c|c|}
\hline $\begin{array}{c}\text { Domains } \\
\text { WHOQOL-bref }\end{array}$ & $\begin{array}{c}\text { Elderly } \\
\text { person's } \\
\text { age } \\
\mathbf{r}_{\mathrm{sp}} \\
\text { (P) }\end{array}$ & $\begin{array}{l}\text { Age of the } \\
\text { caregiver } \\
\mathbf{r}_{\mathrm{sp}} \\
\text { (P) }\end{array}$ & $\begin{array}{c}\text { Per capita } \\
\text { income } \\
\mathbf{r}_{\mathrm{sp}} \\
(\mathrm{P})\end{array}$ & $\begin{array}{c}\text { Number } \\
\text { of people } \\
\text { living in the } \\
\text { household } \\
r_{\mathrm{sp}} \\
\text { (P) }\end{array}$ & $\begin{array}{c}\text { Time as a } \\
\text { caregiver } \\
\mathbf{r}_{\mathrm{sp}} \\
(\mathrm{P})\end{array}$ & $\begin{array}{c}\text { Time } \\
\text { spent } \\
\text { in care }\end{array}$ & $\begin{array}{c}\text { Zarit } \\
\mathbf{r}_{\mathrm{sp}} \\
(\mathrm{P})\end{array}$ & $\begin{array}{c}\text { Katz } \\
\mathbf{r}_{\mathrm{sp}} \\
(\mathrm{P})\end{array}$ \\
\hline QLI & $\begin{array}{c}0.137 \\
(0.305)\end{array}$ & $\begin{array}{c}0.001 \\
(0.993)\end{array}$ & $\begin{array}{c}0.141 \\
(0.292)\end{array}$ & $\begin{array}{l}-0.051 \\
(0.703)\end{array}$ & $\begin{array}{l}-0.013 \\
(0.922)\end{array}$ & $\begin{array}{c}0.026 \\
(0.845)\end{array}$ & $\begin{array}{l}-0.605^{\dagger} \\
(0.000)\end{array}$ & $\begin{array}{l}-0.196 \\
(0.140)\end{array}$ \\
\hline Physical & $\begin{array}{c}0.065 \\
(0.627)\end{array}$ & $\begin{array}{l}-0.260^{*} \\
(0.049)\end{array}$ & $\begin{array}{l}-0.092 \\
(0.491)\end{array}$ & $\begin{array}{l}0.018 \\
(0.894)\end{array}$ & $\begin{array}{l}-0.082 \\
(0.539)\end{array}$ & $\begin{array}{c}0.005 \\
(0.973)\end{array}$ & $\begin{array}{l}-0.513^{\dagger} \\
(0.000)\end{array}$ & $\begin{array}{l}-0.221 \\
(0.095)\end{array}$ \\
\hline Psychological & $\begin{array}{l}-0.117 \\
(0.384)\end{array}$ & $\begin{array}{l}-0.126 \\
(0.344)\end{array}$ & $\begin{array}{c}0.096 \\
(0.473)\end{array}$ & $\begin{array}{l}-0.072 \\
(0.594)\end{array}$ & $\begin{array}{l}0.066 \\
(0.621)\end{array}$ & $\begin{array}{c}0.030 \\
(0.821)\end{array}$ & $\begin{array}{c}-0.507^{\dagger} \\
0.000\end{array}$ & $\begin{array}{l}-0.298 \\
(0.023)\end{array}$ \\
\hline Social relationships & $\begin{array}{l}-0.081 \\
(0.545)\end{array}$ & $\begin{array}{c}0.023 \\
(0.862)\end{array}$ & $\begin{array}{l}-0.024 \\
(0.860)\end{array}$ & $\begin{array}{l}-0.179 \\
(0.179)\end{array}$ & $\begin{array}{l}-0.246 \\
(0.062)\end{array}$ & $\begin{array}{c}0.111 \\
(0.405)\end{array}$ & $\begin{array}{l}-0.283^{*} \\
(0.031)\end{array}$ & $\begin{array}{l}-0.287 \\
(0.029)\end{array}$ \\
\hline Environment & $\begin{array}{c}0.254 \\
(0.054)\end{array}$ & $\begin{array}{c}0.208 \\
(0.117) \\
\end{array}$ & $\begin{array}{c}0.228 \\
(0.085) \\
\end{array}$ & $\begin{array}{c}0.030 \\
(0.823) \\
\end{array}$ & $\begin{array}{c}0.132 \\
(0.325) \\
\end{array}$ & $\begin{array}{c}0.108 \\
(0.418)\end{array}$ & $\begin{array}{l}-0.521 \\
(0.000) \\
\end{array}$ & $\begin{array}{l}-0.057 \\
(0.671)\end{array}$ \\
\hline
\end{tabular}

${ }^{*}$ statistically significant correlation $(p<0.05) ;{ }^{\dagger}$ statistically significant correlation $(p<0.01)$.

The score on the Zarit scale for overload evaluation ranged from 22 to 72 between the caregivers (average of 47 and $\mathrm{SD}=12.3$ ). When applying the multiple linear stepwise forward regression model taking into account gender, morbidity presence, Katz and Zarit scale as independent variables and the QLI as a dependent variable, it was noted that only the Zarit scale remained at the end of the model, indicating that this variable in particular was capable of explaining the QL perception as measured by the QLI. It is thus possible to say that as the caregiver's overload increases, their QL perception becomes worse (Table 3). 
Table 3 - Final multiple linear regression model for the QLI of the study Quality of Life of the Relative Caregiver of Elderly Dependents at Home. Manoel Vitorino, Bahia, 2013

\begin{tabular}{|c|c|c|}
\hline & Coefficient of regression $\beta$ & $\mathrm{p}$ \\
\hline Zarit & -0.783 & 0.002 \\
\hline
\end{tabular}

\section{DISCUSSION}

This study analyzed the association of sociodemographic characteristics and activity overload with the quality of life of relative caregivers of elderly dependents at home in a municipality in the interior of the state of Bahia. The obtained results are confirmed by a previous study ${ }^{15}$ conducted in areas with high HDI; however, the difference between the social context of the subject sample in this study and that of the previous study may have influenced the nature of the relationship between the observed variables.

The predominance of female caregivers with children and in stable relationships is confirmed by the findings of previous nationwide studies $^{15,23-24}$ and international studies. ${ }^{7,25}$ This finding highlights the role of women, who are historically defined as functioning as care providers, ${ }^{23}$ this is seen as natural by women and society, since it is written into the social role of mothers. Caring for elderly family members, therefore, is one more role that women have in the domestic sphere.

Male participation as caregivers is important, $, 15,23-25$ as shown for example in a study conducted in Portugal, 7 which noted an increase in male caregivers. In our study, male caregivers represented only $15.5 \%$ of the sample, showing that although they are in the minority, they also contribute as main caregivers.

Previous studies have already noted that the high age among main caregivers ${ }^{7,15,22,24}$ may be associated with the fact that often this caregiver is a spouse ${ }^{24}$ or even a son or daughter. Our results show an average age of 47 years, with caregivers largely being sons and daughters (77.6\%), followed by spouses $(15.5 \%)$, which justifies the variation in age between 18 and 80 years. The advanced age of the caregivers is a reason for concern, since it may directly influence the risk of overload.

The race/color variable hasn't been reported recently in studies related to relative caregivers. ${ }^{7,15,22-25}$ A study ${ }^{12}$ concerning the profiles of caregivers of elderly persons reported this vari- able and identified that most caregivers declared themselves to be white, which can be related to the southeastern region of Brazil, where the research was conducted. In contrast, this study identified that most of the caregivers declared themselves as black (bi-racial/black), the predominant race/ color in northeast Brazil.

As in other studies, ${ }^{15,22-24}$ the population studied here presents a low educational level, being $67.3 \%$ illiterate or having an incomplete primary school education, which represents a higher percentage than observed in studies ${ }^{9,12}$ conducted in regions of Brazil with high HDI.

Low education may contribute to the role of caregiver being assigned to family members, since entering the labor market is harder for individuals with low education. Thus, it is more probable that these people dedicate themselves to housework and caring for dependent family members as an extension of this activity. ${ }^{15}$

As observed in previous studies, most of the caregivers was unemployed, ${ }^{15,24-25}$ although studies have showed a representative percentage of relative caregivers working in activities outside of their households. ${ }^{7,15,24-25}$ It was noted in the present study that $17.2 \%$ of the caregivers performed paid work in addition to the work performed at home and in the care elderly persons, which may negatively influence the overload and the QL of these caregivers.

Care activity often forces caregivers to decrease their work hours or leave their paid work, especially when the elderly person's situation demands exclusive dedication. ${ }^{24}$ The percentage of unemployed caregivers identified in this study may be associated with this fact, since $74.2 \%$ mentioned having worked outside the home but, at the moment, were exclusively dedicated to unpaid housework.

A study concerning the QL of caregivers of dependent elderly persons showed a per capita income lower than minimum wage among the researched caregivers. ${ }^{15}$ Similarly, this study showed that the highest percentage of caregivers do not have an income, followed by those who receive up to two times the minimum wage. This may be related not only to the time that must be spent on care of the elderly relative, but also to the socioeconomic characteristics of the researched region, which does not have many work opportunities.

A high percentage of caregivers reported the presence of at least one disease, which is confirmed 
by previous studies. ${ }^{7,15}$ Lower back pain diagnosis was the most common, affecting $63.8 \%$ of caregivers, followed by hypertension diagnosis $(41.4 \%)$ and varicose veins $(37.9 \%)$, all pathological conditions that may be related to physical overload. Nevertheless, arterial hypertension ${ }^{15,24}$ and spine conditions ${ }^{22}$ are among the most reported diseases in previous studies.

Many caregivers consider their health normal; their condition tends to worsen due to the process of caring for the elderly person, so that the caregivers themselves need health care. ${ }^{7}$ Comparing the current health status with that in the five previous years, one study ${ }^{24}$ concluded that almost half of the sample reported worse health. This may be related to the practice of care for elderly persons in a home context, by favoring the emergence of limitations in the caregivers lives, with consequent health risks.

When considering the activities of caregivers for elderly persons, a tendency is noted for negative effects related to this function, with an emphasis on physical, psychosomatic, anxiety, depression and stress diseases. However, not all caregivers suffered diseases or became unhappy with the care duty. This may be explained by the use of many individual strategies to deal with situations that are considered stressful. ${ }^{12}$

It was observed that $89.6 \%$ of the researched caregivers have been performing this activity for more one year, $20.8 \%$ of them for more than 10 years. As such, the amount of time spent on care in the researched population was higher than that obtained in the sample of a study ${ }^{15}$ of caregivers of dependent elderly persons conducted in the southern area of the capital of the state of São Paulo. The number of hours spent with care was evaluated in this study, with the conclusion that $82.9 \%$ of the caregivers spend their whole time with family care, which is confirmed by previous studies. $^{22,24}$

Independently, the years spent as a caregiver and the number of hours spent providing care were not significantly correlated with the WHOQOL-bref domains. However, it is possible to infer that, in conjunction, these factors may contribute to a higher perception of work overload and, thus, a worse QL. The circumstances of care may favor negative consequences to the life and health of caregivers, who live with situations of stress, wear and fatigue, ${ }^{12}$ which may cause an additive effect in the perception of work overload and, thus, the perception of QL.
However, even though it is stressful, caring for a family member also presents positive feelings of comfort, accomplishment, and dignity in the lives of caregivers. In this context, it is essential to consider the binomial relationship of caregiver and dependent elderly person, because it demands special attention to health care from health services. ${ }^{24}$

According to the Zarit scale, the population studied here presented a higher overload than observed in other studies. ${ }^{22}$ This may also be related to the longer period of time (in years) and hours dedicated to care, in addition to socioeconomic and cultural factors of the different locations of studies.

It is interesting to observe that the level of overload obtained with the Zarit scale was negatively correlated with all WHOQOL-bref domains and with the QLI, obtaining correlation coefficients higher than those observed in a previous study..$^{15}$ The strong association between the level of overload and the perception of QL observed here may be related to the fact that the Zarit scale was the only explanatory variable to remain in the multiple linear regression model (stepwise forward) applied here, making it possible to say, the higher the overload, the lower the QLI. ${ }^{15}$ This result is confirmed in part by the results of a study ${ }^{15}$ where the Zarit scale was included in the final regression model as an explanatory variable, along with the presence of partner and caregiver disease variables.

As was shown, the stronger association between the Zarit scale and the WHOQOL-bref domains, especially the QLI $\left(\mathrm{r}_{\mathrm{sp}}=0.60\right.$ obtained in that study, against $r_{s p}=0.35$ obtained in the present study $\left.^{15}\right)$, may explain the divergence in the results of the applied regression model. Although there was no observed meaningful correlation between the period of time as a caregiver (in years) and the daily hours dedicated to care and the QL domains, the higher period of time (in years) and hours spent with care observed in our sample in relation to a previous study ${ }^{15}$ may also have contributed to the difference in the results of the regression model, because they represent a longer period of time (in years and hours) of exposure to the overload. This may have impacted the perception of overload in a more significant way, increasing the contribution of the results of the Zarit scale in the final model of regression.

Caregiver QL, evaluated by the WHOQOLbref, presented an average level, as observed in previous studies. ${ }^{7,24}$ The lack of external social op- 
portunities for caregivers and the affected health state of elderly persons appear to converge for a normal result in QL.?

As confirmed by previous studies, ${ }^{7,15}$ the environment and social relationships domains presented the lowest scores, which may be associated with family readaptation in the face of the functional dependence of the elderly person, in addition to a decrease in opportunities for leisure as a result of the time spent with care. Additionally, scarce leisure options, lower purchasing power, precariousness in living conditions and urban mobility, all characteristics of areas with low HDI, may have greatly contributed to the low QL perception concerning environment and social relationships.

With the increase in life expectancy and, resulting increase in the number of elderly citizens, there is also an increase in the number of people who assume the care of a functionally dependent elderly relative. These care activities demand economic resources, time, and family and personal reorganization that generate an overload, which may negatively impact caregivers. A resource that may soften these impacts is the existence of social support networks, inside of which family members find help to satisfy their needs in daily situations. ${ }^{25}$

Caregivers for elderly persons have little support ${ }^{24}$ and can count almost exclusively on the family's informal support network ${ }^{15,25}$ and other community structures. In spite of the problems and shortcomings of support sources, caregivers develop strategies and abilities to deal with the problems they face. ${ }^{25}$ Therefore, there's an evident need to recognize and attend to the needs of caregivers in order to guide them, follow the care and propose actions that look to extend support for the care. ${ }^{26}$

\section{FINAL CONSIDERATIONS}

The results showed that the characteristics of the relative caregivers of elderly dependents are not very different, in both national and international scope, independent of regional or cultural aspects, verifying that most are female, daughters or spouses of the elderly person, married, middleaged, having little education and poor financial condition.

Factors such as work overload are negatively associated with caregiver perception of QL, as seen by analysis of the WHOQOL-bref, with the social relationships and environment domains being having the most influence, which may be worsened by socioeconomic and cultural conditions in areas with low HDI.

Thus, it is clear that there is a need for health actions and social support for relative caregivers, in addition to the definition of public policies directed toward these individuals, having as their objective the promotion of health, the prevention of health risks, and the possibility of minimizing work overload, related to the process of care.

Since Brazil does not in reality have specific policies directed toward caregivers of elderly dependents, it is necessary that health professionals, especially those who work in Family Health Strategies, plan actions and provide aid capable of positively contributing to the QL of these caregivers

\section{REFERENCES}

1. Novais NN, Silva LWS, Gonçalves LHT, Souza TO. Fatores relacionais intrafamiliares na qualidade de vida e saúde de cuidadores de idosos mais idosos - um enfoque sistêmico. Rev Kairós Gerontol. 2011 Jun; 14(3):23-37.

2. Ministério da Saúde (BR). Secretaria de Atenção à Saúde, Secretaria de Gestão do Trabalho e da Educação na Saúde. Guia prático do cuidador. Brasília (DF): MS; 2008.

3. Ministério da Saúde (BR). Secretaria Especial dos Direitos Humanos, Subsecretaria de Promoção e Defesa dos Direitos Humanos Cuidar melhor e evitar a violência: manual do cuidador da pessoa idosa.. Brasília (DF): MS; 2008.

4. Nardi EFR, Oliveira MLF. Conhecendo o apoio social ao cuidador familiar do idoso dependente. Rev Gaúcha Enferm. 2008 Jan-Mar; 29(1)47:53.

5. Brasil. Lei n. 8.842, de 4 de janeiro de 1994: dispõe sobre a Política Nacional do Idoso, cria o Conselho Nacional do Idoso e dá outras providências. Diário Oficial da União. 4 Jan 1994.

6. Brasil. Portaria GM n. 2.528, de 19 de outubro de 2006: aprova a Política Nacional de Saúde da Pessoa Idosa. Diário Oficial da União, Poder Executivo, Brasília (DF); 2006.

7. Gonçalves LHT, Costa MAM, Martins MM, Nassar SM, Zunino R. The family dynamics of elder elderly in the context of Porto, Portugal. Rev Latino-Am Enferm. 2011 May-Jun; 19(3):458-66.

8. Braz E, Ciosak SI. O tornar-se cuidadora na senescência. Esc Anna Nery. 2009 Abr-Jun; 13(2):372-7.

9. Gonçalves LHT, Alvarez AM, Sena ELS, Santana LWS; Vicente FR. Perfil da família cuidadora de idoso doente/fragilizado do contexto sociocultural de Florianópolis-SC. Texto Contexto Enferm. 2006 Out-Dez; 15(4):570-7. 
10. Araújo I, Paúl C, Martins M. Living older in the family context: dependency in self-care. Rev Esc Enferm USP. 2011 Ago; 45(4):866-71.

11. Nickel R. Correlação entre a qualidade de vida de cuidadores familiares e os níveis de independência funcional dos cuidados. Cogitare Enferm. 2010 AbrJun; 15(2):225-30.

12. Gaioli CCLO, Furegato ARF, Santos JLF. Perfil de cuidadores de idosos com doença de Alzheimer associado à resiliência. Texto Contexto Enferm. 2012 Jan-Mar; 21(1):150-7.

13. Fernandes MGM, Garcia TR. Determinantes da tensão do cuidador familiar de idosos dependentes. Rev Bras Enferm. 2009 Jan-Fev; 62(1):57-63.

14. Nardi EFR, Oliveira MLF. Significado de cuidar de idosos dependentes na perspectiva do cuidador familiar. Ciênc Cuid Saúde. 2009 Jul-Set; 8(3):428-35.

15. Amendola F, Oliveira MAC, Alvarenga MRM. Qualidade de vida dos cuidadores de pacientes dependentes no programa de saúde da família. Texto Contexto Enferm. 2008 Abr-Jun; 17(2):266-72.

16. Organização das Nações Unidas (ONU). Ranking do IDH dos Municípios do Brasil. Brasília (DF): Programa das Nações Unidas para o Desenvolvimento. Atlas do Desenvolvimento Humano no Brasil; 2013.

17. The WHOQOL Group. The World Health Organization quality of life assessment (WHOQOL): development and general psychometric properties. Social Science Medicine. 1998 Jun. 46(12):1569-85.

18. Instituto Brasileiro de Geografia e Estatística. Censo: informações das cidades. Rio de Janeiro (RJ): IBGE; 2010.

19. Lino VTS, Pereira SEM, Camacho LAB, Ribeiro Filho ST, Buksman S. Adaptação transcultural da escala de independência em atividades da vida diária (Escala de Katz). Cad Saúde Pública. 2008 Jan; 24(1):103-12.

20. Scazufca M. Brazilian version of the Burden Interview Scale for the assessment of burden of care in carers of people with mental illnesses. Rev Bras Psiquiatr. 2002 Mar; 24(1):12-7.

21. Fleck MPA, Louzada S, Xavier M, Chachamovich E, Vieira G, Santos L, et al. Aplicação da versão em português do instrumento abreviado de avaliação da qualidade de vida "WHOQOL-bref". Rev Saúde Pública. 2000 Mar-Abr; 34(2):178-83.

22. Oliveira DC, Carvalho GSF, Stella F, Higa CMH, D’Elboux MJ. Qualidade de vida e sobrecarga de trabalho em cuidadores de idosos em seguimento ambulatorial. Texto Contexto Enferm. 2011 Abr-Jun; 20(2):234-40.

23. Stackfleth R, Diniz MA, Fhon JRS, Vendruscolo TRP, Fabrício-Whebe SCC, Marques S, et al. Sobrecarga de trabalho em cuidadores de idosos fragilizados que vivem no domicílio. Acta Paul Enferm. 2012 Out-Nov; 25(5):768-74.

24. Pimenta GMF, Costa MASMC, Gonçalves LHT, Alvarez AM. Profile of the caregiver of dependent elderly family members in a home environment in the city of Porto, Portugal. Rev Esc Enferm USP. 2009 Set; 43(3):606-11.

25. Guedea MTD, Damacena FA, Carbajal MMM, Marcobich PO, Hernández GA, Lizárraga LV, et al. Social support needs of mexican elders family caregivers. Psicol Soc. 2009 Mai-Ago. 21(2):242-49.

26. Floriano LA, Azevedo RCS, Reiners AAO, et al. Care performed by family caregivers to dependent elderly, at home, within the context of the family health strategy. Texto Contexto Enferm. 2012 JulSet. 21(3):543-8 